\title{
Current Nomenclature of Pseudohypoparathyroidism: Inactivating Parathyroid Hormone/Parathyroid Hormone-Related Protein Signaling Disorder
}

\author{
Serap Turan \\ Marmara University Faculty of Medicine, Department of Pediatric Endocrinology, Istanbul, Turkey
}

\begin{abstract}
Disorders related to parathyroid hormone (PTH) resistance and PTH signaling pathway impairment are historically classified under the term of pseudohypoparathyroidism (PHP). The disease was first described and named by Fuller Albright and colleagues in 1942. Albright hereditary osteodystrophy (AHO) is described as an associated clinical entity with PHP, characterized by brachydactyly, subcutaneous ossifications, round face, short stature and a stocky build. The classification of PHP is further divided into PHP-Ia, pseudo-PHP (pPHP), PHP-Ib, PHP-IC and PHP-II according to the presence or absence of AHO, together with an in vivo response to exogenous PTH and the measurement of Gs $\alpha$ protein activity in peripheral erythrocyte membranes in vitro. However, PHP classification fails to differentiate all patients with different clinical and molecular findings for PHP subtypes and classification become more complicated with more recent molecular characterization and new forms having been identified. So far, new classifications have been established by the EuroPHP network to cover all disorders of the PTH receptor and its signaling pathway. Inactivating PTH/PTH-related protein signaling disorder (iPPSD) is the new name proposed for a group of these disorders and which can be further divided into subtypes - iPPSD1 to iPPSD6. These are termed, starting from PTH receptor inactivation mutation (Eiken and Blomstrand dysplasia) as iPPSD1, inactivating Gs $\alpha$ mutations (PHP-Ia, PHP-IC and pPHP) as iPPSD2, loss of methylation of GNAS DMRs (PHP-Ib) as iPPSD3, PRKAR1A mutations (acrodysostosis type 1) as iPPSD4, PDE4D mutations (acrodysostosis type 2) as iPPSD5 and PDE3A mutations (autosomal dominant hypertension with brachydactyly) as iPPSD6. iPPSDx is reserved for unknown molecular defects and iPPSDn +1 for new molecular defects which are yet to be described. With these new classifications, the aim is to clarify the borders of each different subtype of disease and make the classification according to molecular pathology. The iPPSD group is designed to be expandable and new classifications will readily fit into it as necessary.
\end{abstract}

Keywords: Pseudohypoparathyroidism, inactivating parathyroid hormone/parathyroid hormone related protein signaling disorder

\section{Introduction}

Pseudohypoparathyroidism (PHP) is a group of rare, related, highly heterogeneous disorders, which are characterized by end-organ resistance to parathyroid hormone (PTH) action. PHP and related disorders are caused by the genetic and/or epigenetic changes leading to down-regulation of a cyclic adenosine monophosphate (CAMP) generator, mostly related to the GNAS gene $(1,2,3,4,5)$. GNAS is an imprinted gene which gives rise to multiple gene products, including transcripts that encode the $\alpha$-subunit of the stimulatory guanine nucleotide-binding protein (G protein) (Gs $\alpha$ ), extralarge Gsa (XLas), and neuroendocrine secretory protein 55
(NESP55), as well as to noncoding $A / B$ (also referred to as $1 A)$ and antisense transcripts (GNAS-AS1).

Gs $\alpha$ is a ubiquitously expressed signaling protein having a role in the actions of many hormones and other endogenous molecules through the generation of intracellular CAMP and encoded by GNAS exons $1-13(1,2,3,4,5)$. Other GNAS transcripts NESP55, XLaS, and $A / B$, with the exception of GNAS-AS1 consists of distinct exons, and all contain their own, differentially methylated, unique first exons (DMRs), which are spliced onto exon 2 of GNAS. So all of these transcripts, from exon 2 on, are identical in sequence to $\operatorname{Gs} \alpha(6,7,8,9,10,11)$. Thus a structural or epigenetic change in other GNAS trancripts also affects Gs $\alpha$ function. 
Expression patterns of Gs $\alpha$ and other GNAS transcripts in different tissues determine the disease phenotype when GNAS mutations are present. The Gs $\alpha$ transcript is biallelically expressed in most tissues. However, silenced paternal Gs $\alpha$ expression in some tissues, including proximal renal tubules, neonatal brown adipose tissue, thyroid, gonads, the paraventricular nucleus of the hypothalamus and pituitary can cause hormone resistance in cases of maternal mutations $(12,13,14,15,16,17,18)$. Thus, mutations on maternal alleles cause hormone resistance i.e. PHP.

Historically PHP is the first hormone-resistance syndrome, described by Albright et al (19) and characterized by hypocalcemia, hyperphosphatemia, and elevated PTH levels and Albright hereditary osteodystrophy (AHO). Clinical features of AHO are obesity, round face, short stature, brachydactyly (BD), subcutaneous ossifications and mental retardation. AHO features occur regardless of the parental origin of the Gs $\alpha$ mutation, because AHO features are thought to result from Gs $\alpha$ haploinsufficiency, primarily in those tissues where Gs $\alpha$ expression is biallelic. Consistent with this interpretation, changes in growth plate chondrocytes and subcutaneous ossifications occur, regardless of whether the disrupted allele is inherited from the mother or the father $(20,21)$. Thus, AHO features are seen both in patients with maternal mutations i.e. PHP and paternal mutations, e.g. pseudo-PHP (pPHP), which is characterized by absence of PTH and/or hormonal resistance (Table 1). However, recent data from human studies have revealed that Gs $\alpha$ imprinting may be present in some features of AHO, that is obesity and cognitive impairment occur predominantly in patients with PHP $(22,23)$.

\section{Pseudohypoparathyroidism Classification}

PHP is subdivided into type I and type II. Type I is defined as the failure to increase both urinary cAMP and urinary phosphate excretion in response to exogenous PTH administration $(1,2,3,4,5,24)$. In PHP-II, urinary cAMP generation in response to exogenous PTH administration is normal, but the urinary excretion of phosphate is impaired (25). Although the common biochemical features of PTH resistance are hypocalcemia, hyperphosphatemia, and elevated PTH levels, and found in PHP-Ia, PHP-Ic, and PHP$\mathrm{Ib}$; AHO is the part of clinical picture in PHP-Ia, PHP-Ic, pPHP and occasionally in PHP-Ib. In PHP-Ia/PHP-Ic, in addition to PTH resistance, hypothyroidism, growth hormone deficiency and hypogonadism are also demonstrable reflecting target-organ resistance to thyroid-stimulating hormone (TSH), growth hormone-releasing hormone (GHRH) and gonadotropins, respectively $(1,2,3,4,5)$.
This complex classification of PHP is based on several distinct criteria, including the presence of AHO features, hormone resistance, urinary CAMP and phosphaturic response to exogenous PTH and Gs $\alpha$ activity (Table 1). However, there are some combinations of features which do not fit readily into this classification, especially with recent development in the field.

\section{Controversies in Pseudohypoparathyroidism Type I}

The presence or absence of hormonal resistance is the one of the key findings, which differentiates PHP from pPHP, maternal from paternal mutations, respectively. However, mild resistance to PTH and possibly to other hormones such as TSH, has been described in patients carrying a paternal GNAS mutation, that is patients with pPHP (26), so that hormonal resistance is now not only associated with PHP, but with pPHP as well.

Another cornerstone of the earlier classification of PHP is presence or absence of features of AHO, which differentiates PHP-Ia/PHP-Ic from PHPI-b. However, a number of reports from the last decade have also shown that AHO features can exist in patients with epigenetic abnormalities of GNAS or namely PHP-Ib $(27,28,29,30)$. Furthermore, GNAS methylation changes reminiscent of PHP-Ib have been reported in PHP-Ia patients with GNAS deletions (31). These findings suggest a molecular and clinical overlap between the two subtypes.

The measurement of Gs $\alpha$ protein activity from erythrocyte membranes is one diagnostic method used for differentiating PHP-Ic from PHP-Ia/pPHP, in patients with AHO features and carrying GNAS coding mutations. Additionally, according to the previous criteria, Gs $\alpha$ activity is expected to be normal in patients with PHP-Ib $(1,2,3,4,5,6)$. However, recently PHPIb patients have been shown to have a moderate reduction in Gs $\alpha$ activity, in a similar but less severe manifestation as patients with PHP-Ia/pPHP (32). Thus, PHP-Ib patients having methylation abnormalities and with AHO features might also have low Gs $\alpha$ activity and the clinical and biochemical findings of these patients are consistent with PHP-Ia (32). On the other hand, if Gs $\alpha$ activity is normal in the patient with PHP-Ib and AHO features, the patients could be described as PHP-Ic, clinically and biochemically $(27,28,29,30,32)$.

Additionally, molecular defects are not unique to PHP-Ic. The lossof-function mutations in the carboxyl-terminus of GNAS, causing disruption of receptor-mediated activation but conservation of adenylyl cyclase receptor-independent activation, lead to PHPIc $(33,34,35)$. And methylation defects, as found in PHP-Ib could be another molecular defect present in patients described clinically and biochemically as PHP-Ic (34). 
Table 1. Disease related parathyroid hormone/parathyroid hormone-related protein and cyclic adenosine monophosphate signaling pathway and former classification according to clinical features and molecular defects

\begin{tabular}{|c|c|c|c|c|c|c|c|}
\hline & $\begin{array}{l}\text { Molecular } \\
\text { defects }\end{array}$ & $\begin{array}{l}\text { Parental } \\
\text { origin }\end{array}$ & $\begin{array}{l}\text { Hormonal } \\
\text { abnormalities }\end{array}$ & $\begin{array}{l}\text { Additional } \\
\text { clinical features }\end{array}$ & $\begin{array}{l}\text { Urinary } \\
\text { cAMP to } \\
\text { exogenous } \\
\text { PTH }\end{array}$ & $\begin{array}{l}\text { Urinary } \\
\text { phosphate } \\
\text { to } \\
\text { exogenous } \\
\text { PTH }\end{array}$ & $\begin{array}{l}\text { Erythrocyte } \\
\text { Gs } \alpha \text { activity }\end{array}$ \\
\hline $\begin{array}{l}\text { PHP Ia } \\
\text { (OMIM \# 103580) }\end{array}$ & $\begin{array}{l}\text { Gs } \alpha \text { coding } \\
\text { mutations- } \\
\text { inactivating }\end{array}$ & Maternal & $\begin{array}{l}\text { PTH resistance } \\
\text { TSH resistance } \\
\text { Other hormone } \\
\text { resistances (GHRH, } \\
\text { gonadotrophins, } \\
\text { calcitonin, etc.) }\end{array}$ & AHO features & Blunted & Blunted & Reduced \\
\hline $\begin{array}{l}\text { PHP IC } \\
\text { (OMIM \#612462) }\end{array}$ & $\begin{array}{l}\text { Gs } \alpha \text { coding } \\
\text { mutations- } \\
\text { inactivating }\end{array}$ & Maternal & $\begin{array}{l}\text { PTH resistance } \\
\text { TSH resistance } \\
\text { Other hormone } \\
\text { resistances (GHRH, } \\
\text { gonadotrophins, } \\
\text { calcitonin, etc.) }\end{array}$ & AHO features & Blunted & Blunted & Normal \\
\hline $\begin{array}{l}\text { POH } \\
\text { (OMIM \# 166350) }\end{array}$ & $\begin{array}{l}\text { Gs } \alpha \text { coding } \\
\text { mutations- } \\
\text { inactivating }\end{array}$ & Paternal & No & No & Normal & Normal & Reduced \\
\hline $\begin{array}{l}\text { PHP Ib } \\
\text { (OMIM \#603233) }\end{array}$ & $\begin{array}{l}\text { Methylation } \\
\text { defects }\end{array}$ & Maternal & $\begin{array}{l}\text { PTH resistance } \\
\text { TSH resistance }\end{array}$ & No & Blunted & Blunted & Normal \\
\hline $\begin{array}{l}\text { Acrodysostsosis } \\
\text { type } 1 \\
\text { (OMIM \#101800) }\end{array}$ & $\begin{array}{l}\text { PRKAR1A } \\
\text { mutations- } \\
\text { leading } \\
\text { reduced PKA } \\
\text { activity }\end{array}$ & $\begin{array}{l}\text { Autosomal } \\
\text { dominant }\end{array}$ & $\begin{array}{l}\text { PTH resistance } \\
\text { TSH resistance in } \\
\text { some }\end{array}$ & $\begin{array}{l}\text { AHO } \\
\text { Typical face }\end{array}$ & Normal & Blunted & Normal \\
\hline $\begin{array}{l}\text { Hypertension and } \\
\text { brachydactyly } \\
\text { Syndrome (OMIM } \\
\text { \#112410) }\end{array}$ & $\begin{array}{l}P D E 3 A \\
\text { mutations- } \\
\text { activating }\end{array}$ & $\begin{array}{l}\text { Autosomal } \\
\text { dominant }\end{array}$ & Unknown & $\begin{array}{l}\text { AHO } \\
\text { Hypertension }\end{array}$ & Unknown & Unknown & Unknown \\
\hline $\begin{array}{l}\text { Blomstrand } \\
\text { chondrodysplasia } \\
\text { (OMIM \#215045) }\end{array}$ & $\begin{array}{l}\text { PTH1R } \\
\text { mutations- } \\
\text { inactivating }\end{array}$ & $\begin{array}{l}\text { Autosomal } \\
\text { recessive }\end{array}$ & Unknown & $\begin{array}{l}\text { Severe skeletal } \\
\text { dysplasia, } \\
\text { Lethal, abnormal } \\
\text { breast and tooth } \\
\text { development, } \\
\text { Accelerated } \\
\text { ossification }\end{array}$ & Unknown & Unknown & Unknown \\
\hline $\begin{array}{l}\text { Eiken syndrome } \\
\text { (OMIM \#600002) }\end{array}$ & $\begin{array}{l}\text { PTH1R } \\
\text { mutations- } \\
\text { inactivating }\end{array}$ & $\begin{array}{l}\text { Autosomal } \\
\text { recessive }\end{array}$ & $\begin{array}{l}\text { PTH resistance } \\
\text { (mild) }\end{array}$ & $\begin{array}{l}\text { Severe skeletal } \\
\text { dysplasia, dwarfism, } \\
\text { Retarded ossification }\end{array}$ & Unknown & Unknown & Unknown \\
\hline
\end{tabular}


There are too many inconsistencies described in the literature of PHP-I subtypes, both clinically, genetically and biochemically when using the earlier classification so that a newer, comprehensive classification would be welcome.

Furthermore, progressive osseous heteroplasia ( $\mathrm{POH}$ ) is a distinct entity described in patients with paternally inherited GNAS mutations, usually causing truncation of the gene product (36). Features typical of $\mathrm{AHO}$ and hormone resistance have been detected in some patients with $\mathrm{POH}$. Conversely, some PHP-Ia patients with maternal mutations present with $\mathrm{POH}$-like progressive deepening of the heterotopic ossifications $(37,38)$. Furthermore, $\mathrm{POH}$ lesions show a mosaic distribution and follow dermomyotomes, usually with a unilateral pattern. Experimental evidence has shown that a loss of heterozygosity at the GNAS locus, with somatic mutations in a progenitor cell of somitic origin, may cause severe, progressive heterotopic ossifications that show a similar unilateral distribution (39).

\section{Controversies in Pseudohypoparathyroidism Type II}

The differentiation of PHP-I from PHP-II is made by comparing the in vivo response to exogenous PTH in terms of nephrogenic CAMP synthesis and phosphaturia. The presence of CAMP elevation without phosphaturia marks PHP-II (24,25). Until 2011 no clear etiopathogenesis had been described for PHP-II (40). However, then and since, patients with acrodysostosis, have been found to exhibit biochemical abnormalities found in PHP-II. In addition, heterozygous mutations in PRKAR1A, which encodes the regulatory subunit of protein kinase $A$ (PKA) and PDE4D, which encodes phosphodiesterase type 4 , have been found in patients with acrodysostosis $(40,41,42)$. Both PRKAR1A and PDE $4 D$ have a role in CAMP generation, down stream of Gs $\alpha$. Thus, a heterogeneous group of rare diseases, characterized by skeletal dysplasia, has been included in the classification of PHP.

Acrodysostosis is characterized by skeletal dysplasia and has characteristic features, including BD, facial dysmorphism and, in some cases, mental retardation $(43,44,45,46,47)$. Hormone resistances, usually PTH and/or TSH resistance, have been detected in about $60-70 \%$ of acrodysostosis patients with a PRKAR $1 A$ mutation and in 10-20\% of cases with PDE4D mutations. However, typical facial features and more generalized $\mathrm{BD}$ distinguishes acrodysostosis from PHP $(46,48)$. On the other hand, it has been shown that some cases with a phenotype typical of PHP-Ia also have PRKAR1A mutations $(49,50)$.

Another disease that has been shown to involve the cAMP pathway is hypertension and brachydactyly syndrome (HTNB-Bilginturan syndrome, OMIM \#112410) which is characterized by hypertension, BD type $\mathrm{E}(\mathrm{BDE})$ and short stature. Heterozygous mutations in $P D E 3 A$ have been identified in patients affected with HTNB (51). Of note, BDE and short stature are clinical features of AHO.

Although these two diseases, acrodysostosis and HTNB syndrome exhibit molecular defects in the PTH-cAMP pathway and are clinically identical to PHP/pPHP, they were not previously included in the classification of PHP. Furthermore, disorders associated with an impaired function of PTH1R, i.e. Blomstrand and Eiken skeletal dysplasia, are also currently not included in the classification of PHP. In addition, other diseases featuring defects in CAMP and its downstream pathway, should have a place in the classification if they are described in the future.

\section{Rationale for the New Classification}

In light of this new evidence the EuroPHP network, which is composed of experts from different independent centres, proposed a new classification to create a uniform terminology and classification based on the current knowledge of PHP (52). The term "inactivating PTH/PTHrP signalling disorder" (iPPSD) was selected since it describes the common mechanism responsible for the diseases, encompasses all disorders related to this pathway and was flexible enough to incorporate new development in this field (52).

The terms "PHP" and "pPHP" are confusing, both for description of the diseases and for use in communication. iPPSD is more compact and describes a group of disorders which makes the disease classification easier from the beginning. For the diagnosis of iPPSD, major and minor criteria have been described and a minimum of one of the major criteria is mandatory for clinical diagnosis of iPPSD (see Table 2) (52). PTH resistance or ectopic ossifications could be diagnostic for iPPSD with or without the presence of minor criteria. However, since BDE is a common feature of several other diseases and syndromes, in patients exhibiting BDE at least one major or two minor criteria should also be present for a diagnosis of iPPSD.

The entities included in iPPSD classification, with known molecular causes of impaired PTH/parathyroid hormonerelated protein (PTHrP) signaling (52) are:

- Inactivating mutations of PTH1R

- Heterozygous inactivating mutations in the coding sequence of GNAS-Gs $\alpha$

- Methylation changes of the DMRs of GNAS caused by deletions or duplications (STX16; NESP; GNAS-AS1) or paternal UPD of chromosome 20q or unknown mechanism(s)

- Heterozygous mutations of PRKAR1A leading to reduced PKA activity 
- Heterozygous activating mutations of PDE4D

- Heterozygous activating mutations of PDE3A

\section{Major and Minor Criteria}

\section{Major Criteria}

1. PTH resistance: PTH resistance is defined as elevated PTH with or without hypocalcemia, hyperphosphatemia. Resistance occurs only at the renal proximal tubule and distal renal tubule and PTH is functionally intact and therefore, the patients will have hypocalciuria $(1,2,3,4,5)$.

For evaluation of PTH resistance and to differentiate PTH resistance from normocalcaemic hyperparathyroidism, renal failure, vitamin $\mathrm{D}$ deficiency and any form of secondary hyperparathyroidism, the following laboratory tests should be performed; ionized calcium, total calcium, phosphate, magnesium, PTH, vitamin D (25-hydroxyvitamin $D$ ), creatinine, urinary calcium and urinary phosphate excretion. A PTH infusion test is reserved for challenging cases $(1,2,3,4,5,52)$.

2. Ectopic ossification: Ectopic ossifications are foci of bone formation in the adipose or dermal tissue, which manifest as superficial, subcutaneous nodules $(1,2,3,4,5)$. Progression of heterotopic osseous calcifications, usually from the dermal and subcutaneous tissues to the deeper tissues, such as muscles and tendons may be seen and defined as $\mathrm{POH}(36,37,38)$. In children, ectopic ossifications are highly suggestive of an inactivating GNAS mutation, i.e. iPPSD (52).

Table 2. Diagnosis of inactivating parathyroid hormone/ parathyroid hormone-related protein signalling disorder with major and minor criteria

\section{Major criteria}

1. PTH resistance

2. Ectopic ossification

3. Brachydactyly type $\mathrm{E}$

\section{Minor criteria}

1. TSH resistance

2. Other hormonal resistances

3. Motor and cognitive retardation or impairment

4. Intrauterine and postnatal growth retardation

5. Obesity/overweight

6. Flat nasal bridge and/or maxillar hypoplasia and/or round face

Parathyroid hormone/parathyroid hormone-related protein signalling disorder clinical diagnosis: Either presence of one major criteria, either number 1 or 2 ; or presence of major criteria number 3 and at least 2 minor criteria

PTH: parathyroid hormone, TSH: thyroid-stimulating hormone
Diagnosis of ectopic calcification can be made by inspection and palpation on physical examination and may be detected by X-ray imaging if tissue is large enough. In selected cases, diagnosis may involve biopsy, but it is not recommended due to an increased risk for progression of biopsied osseous tissue (52). Fibrodysplasia ossificans progressiva (OMIM \#135100) and post-traumatic osteoma cutis should be differentiated (53). Calcification rather than ossification should be considered as a differential diagnosis, as in tumoral calcinosis which is related to the defective activity of fibroblast growth factor 23 (FGF23), in which mutations in FGF23, GALNT3 and $\alpha$-klotho have been identified (54).

3. BDE: $\mathrm{BD}$ refers to shortening of the fingers, toes or both. BD in iPPSD should be classified as BDE (OMIM \#113300), which is characterized by variable shortening of the metacarpals, with more or less normal length of phalanges, occasionally accompanying shortened metatarsals (55). Hypoplastic and partially fused metacarpal epiphyses, seen on radiographs, are the cause of $\mathrm{BD}$ and lead to $\mathrm{BDE}$. In addition, the terminal phalanges are often short (55). It can either present in isolation or as part of a genetic disorder, most of which are included in the iPPSD classification (56).

Almost all patients with GNAS mutations have $\mathrm{BD}$ and decreased Gs $\alpha$ activity, which is usually decreased by around $50 \%(57,58,59)$. Although, Gs $\alpha$ activity is supposed to be normal in cases with methylation abnormalities such as in the entity known as PHP-Ib formerly, PHP-Ib patients with an AHO phenotype have more severely diminished Gs $\alpha$ activity levels than those who do not have the AHO phenotype (32). Furthermore, BD has been detected in both patients with a genetic mutation and in those with an imprinting error in PHP-Ib but at differing median ages of detection; 7.2 years in the former and 13.2 years in the latter (60). These results could be related to the degree of the Gs $\alpha$ functional impairment with a more severe loss of function leading to earlier BD development. It can be difficult to detect $\mathrm{BD}$, especially in early childhood, and tends to become more evident during early puberty. BD can be overlooked when all bones are short as in acrodysostosis which has affected the patient since early childhood (61).

Clinical and radiological evaluation of hand bones are necessary for a diagnosis of BDE. On clinical examination, by using a straight ruler at the head of the metacarpals of the closed fist, the tips of $3^{\text {rd }}, 4^{\text {th }}$ and $5^{\text {th }}$ metacarpals should be in a line and touching the ruler. If the $4^{\text {th }}$ or $5^{\text {th }}$ metacarpals are receding, this can be accepted as a positive metacarpal sign, also known as Archibald's sign $(55,62,63)$. The evaluation on X-rays can be done in a similar fashion $(55,63)$. However, normally this sign is positive in only $9.6 \%$ of individuals and if a deviation of more than 2 
$\mathrm{mm}$ is accepted as a limit, only $0.5 \%$ of individuals have the sign (64). In addition, if all bones are short, this metacarpal sign will be negative. If so, each metacarpal and phalangeal bone should be measured and evaluated separately (metacarpo-phalangeal profile). If shorter than 2 standard deviation scores (SDS) for the individual bone, it is accepted as short and BD (65). Differential diagnoses for BDE are Turner syndrome, tricho-rhino-phalangeal syndrome (TRPS) including TRPS type I, (OMIM \#190350), TRPS type II (OMIM \#150230) and TRPS type III, (OMIM \# 190351), BDE with short stature, parathyroid hormone-like hormone (PTHLH, OMIM \#613382), isolated BDE: HOXD13 type (OMIM \# 113300) and BD mental retardation syndrome (OMIM \#600430) (56).

While existence of PTH resistance or ectopic ossifications are considered diagnostic for iPPSD as major criteria; BD is less specific and should, therefore, be present with at least one other major or two minor criteria to consider the diagnosis of iPPSD.

\section{Minor Criteria}

\section{Thyroid-Stimulating Hormone Resistance}

TSH resistance is usually characterized by mildly elevated TSH levels with a normal or low-normal free thyroxine (T4) level. TSH levels are usually below $50 \mathrm{mIU} / \mathrm{L}(66,67)$. Sometimes patients present with clinical symptoms of hypothyroidism, such as prolonged jaundice, macroglossia, hypothermia and umbilical hernia in neonates or constipation and listlessness in infants $(66,68)$.

Hypothyroidism occurs in the absence of goiter and markers of autoimmune disease $(66,67)$. In laboratory evaluation, TSH, free-T4, anti-thyroid antibodies and thyroid ultrasound should be performed. TSH receptor inactivation mutation can be considered in the differential diagnosis $(52,66,67)$.

TSH resistance could be a first manifestation of iPPSD, especially if referred from the neonatal screening program for congenital hypothyroidism $(68,69)$.

\section{Other Hormone Resistances}

Other hormone resistances are also present in iPPSD. Growth hormone deficiency due to resistance to GHRH, is the next most frequent resistance reported, and found in $60 \%$ of patients with PHP-Ia $(70,71,72)$. Calcitonin resistance has also been also described in patients with PHP-Ia, but with no known associated clinical or biochemical abnormalities (67). Gonadotropin resistance, with elevated follicle-stimulating hormone (FSH) and luteinizing hormone (LH) levels, is a further G-protein coupled hormone resistance reported in iPPSD $(73,74)$. Glucagon and adrenaline resistances have been demonstrated through in vivo testing in patients with low Gs $\alpha$ bioactivity $(75,76)$.
For evaluation of growth hormone deficiency; insulinlike growth factor (IGF)-1, IGFB-3 and growth hormone stimulation tests can be performed, if necessary. Serum measurements of calcitonin, LH and FSH are helpful if the respective resistance is suspected and in addition a gonadotropin-releasing hormone/LH-releasing hormone test may be performed.

\section{Motor and Cognitive Retardation or Impairment}

Psychomotor and cognitive impairments have been described as a feature of AHO. A significant proportion of patients (40$70 \%$ ) with a maternal coding mutation of GNAS, (formerly PHP-Ia) has been shown to have cognitive impairment $(22,77)$. However, cognitive impairment is seen rarely in patients with paternally inherited GNAS mutations (PPHP, $\mathrm{POH}$ ) ranging from $0 \%$ to $10 \%$ of cases (78). The patients with methylation abnormalities, i.e. PHP-Ib, may also have cognitive impairment $(79,80,81)$ especially if they have AHO features, as cognitive impairment is reported in almost half of them (30). Additionally, varying severity of psychomotor and cognitive impairment has been described in some patients with acrodysostosis $(42,44,45)$. It has been suggested that psychiatric disorders may be part of the disease spectrum (82). However, patients with paternal mutations of GNAS or epigenetic modifications of GNAS DMRs seem to be unaffected $(22,83)$.

\section{Intrauterine and Postnatal Growth Retardation}

Intrauterine growth retardation (IUGR) has been frequently observed in patients with inactivating GNAS coding mutations. Although both paternal and maternal inherited mutations are associated with IUGR, patients harbouring mutations on the paternal GNAS allele are more severely affected, especially when the mutation is in exons 2 to 13, compared with patients with GNAS exon 1 /intron 1 mutations (84). The reason for paternal GNAS exon 2-13 mutations causing more severe IUGR is due to an impairment of another transcript of GNAS, XLas, which is essential for early postnatal adaptation to feeding and survival, as well as glucose counterregulation $(85,86)$. IUGR has also been described in other iPPSD, such as acrodysostosis with mutations in PRKAR1A or PDE4D, and in patients with mutations in PDE3A $(40,41,49,51)$. However, loss of methylation at the maternal GNAS $A / B$ : PHP-1b has been associated with increased intrauterine growth and high birth weight (87).

Postnatal growth retardation resulting in short final height is a common finding in PHP-la and acrodysostosis. Growth hormone deficiency and premature closure of the epiphysis are the causes of short stature $(40,41,70,88)$. Rarely, growth retardation has also been described in PHP-Ib $(27,30)$ and in patients with Eiken dysplasia (89). 


\section{Obesity/Overweight}

Obesity or overweight is commonly present but, is possibly the most nonspecific minor sign of iPPSD. However, early onset obesity is an important clinical feature manifesting from the first few months of life and resulting in severe obesity during infancy. However, obesity tends to improve as the patient ages. In adulthood, only about two thirds of PHP-Ia are obese with a mean body mass index (BMI) Z-score of $1.7 \pm 0.2(77,90,91)$.

Patients with maternally inherited GNAS coding exon mutations, but not those carrying mutations on the paternal allele, have obesity/overweight. This may be helpful in differentiating PHP-Ia from pPHP. Growth hormone deficiency, impaired lipolytic response to adrenaline (76) or decreased resting energy expenditure (92) may all contribute to the development of obesity in patients with mutations on the maternal allele $(23,91)$. Obesity is also a frequent feature in patients affected with acrodysostosis $(40,49,93)$. For evaluation, weight charts and BMI SDS or percentile charts are necessary. Monogenic obesity stemming from leptin/ melanocortin pathway abnormalities should be considered in differential diagnosis of early onset obesity (94).

\section{Flat Nasal Bridge and/or Maxillar Hypoplasia and/or Round Face}

Patients with acrodysostosis have typical facial features with flat nasal bridge and/or maxillar hypoplasia and patients with PHP-Ia have a round face which is inconsistent with the degree of obesity. These findings are, however, nonspecific $(19,45)$.

\section{The New Classification (Figure 1)}

The former classification of PHP/pPHP is based on the clinical and biochemical phenotype. However, a new classification, iPPSD, has been identified according to described clinical and biochemically criteria. Further subtyping will be possible by identifying the underlying molecular genetic or epigenetic defect. Thus, the term iPPSD refers to the pathophysiology, which is impairment of PTH/ PTHrP signaling, and the number refers to the underlying molecular defect as shown below (52).

\section{Inactivating PTH/PTHrP Signalling Disorder (iPPSD)}

- Clinical/biochemical diagnosis based on the major/minor criteria as defined
- Bloostrand \& Eiken dysplasia. PHP1 \&PHP2. pPHP/AHO/POH. Acrodysostosis. HTNB
- Inactivating PTHR1 mutations

Figure 1. The new classification proposed by the European Pseudohypoparathyroidism Network (52) with new nomenclature on the left with molecular defects and the disease names listed in the right column

PTH: parathyroid hormone, PTHrP: parathyroid hormone-related protein, iPPSD: inactivating parathyroid hormone/parathyroid hormone-related protein signaling disorder, DMRs: differentially methylated regions, POH: progressive osseous heteroplasia, PHP: pseudohypoparathyroidism, pPHP: pseudopseudohypoparathyroidism, AHO: Albright hereditary osteodystrophy, PKA: protein kinase A, HTNB: hypertension and brachydactyly syndrome 
The Classification of Inactivating PTH/PTHrP Signalling Disorder (52)

iPPSD: Clinical/biochemical diagnosis based on the major/ minor criteria described, without any genetic investigation/ diagnosis.

iPPSD1: Loss-of-function mutation in PTH1R.

iPPSD2: Loss-of-function mutation in Gs $\alpha$.

iPPSD3: Methylation change(s) at one or more GNAS DMRS, associated with or without a genetic deletion (STX16, NESP55, AS etc.) or cytogenetic (UPD) defect. The loss of methylation at the GNAS $A / B$ is the common mechanism shared by these patients.

iPPSD4: Mutation in PRKAR1A leading reduced PKA activity.

iPPSD5: Gain-of-function mutation in PDE4D mutation.

iPPSD6: Gain-of-function mutation in PDE3A mutation.

iPPSDx: Absence of any genetic/epigenetic defect after molecular investigations of known genes described above but fitting the criteria for iPPSD.

iPPSDn + 1: Identification of a new gene and/or molecular defect will increment the number of iPPSD types by one, i.e. iPPSD7, iPPSD8 and so on.

With this new classification, the disorders were stratified according to etiopathogenesis, thus mechanism and simplified the concept of the overlapping disorders under a single umbrella. Additionally, it is flexible enough to accommodate new defects which may be discovered in the future. However, with this classification, the parental origin of the genetic/epigenetic defect is not taken into account, although iPPSD2 and iPPSD3 are imprinting disorders and their clinical presentation depends on the parental origin of inheritance. Although multiple hormone resistance, including PTH resistance, are largely associated with maternal GNAS mutations and isolated AHO and/or $\mathrm{POH}$ are more often associated with paternal GNAS mutations, hormone resistance and POH may be seen in both maternal and paternal inactivating GNAS mutations. Therefore, the new classification does not include parental origin of mutation but for genetic counseling this point should be considered. The mechanism of the two allelic GNAS mutations can be considered alike. Another point of this classification is the inability to sub-classify individuals with purely clinical findings-molecular analysis is mandatory. Cases should be classified as iPPSD, not iPPSDx, pending definitive molecular diagnosis.

Furthermore, PTHR1 has been included in the classification. However, two main ligands of PTHR1, PTH and PTHrP and related disorders are not chosen as a part of classification.
Since, BDE with short stature seen in patients with PTHLH mutations, encoding PTHrP, $(95,96)$, this point could be argued. Since these disorders are not primarily related to the signaling pathway defect, it is not included in the definition of main classification.

\section{Conclusion}

A new classification has been established by the EuroPHP network to cover all disorders of the PTH receptor and its signaling pathway. iPPSD is the new name proposed for this group of conditions and which are further divided into the subtypes from iPPSD1 to iPPSD6. With this new classification, it is aimed to clarify the border of each different subtype of disease and make the classification according to molecular pathology. The iPPSD group is a growing group of conditions and new entities can readily be fitted into this classification.

\section{Ethics}

Peer-review: Internally peer-reviewed.

Financial Disclosure: The author declared that this study received no financial support.

\section{References}

1. Mantovani G. Clinical review: Pseudohypoparathyroidism: diagnosis and treatment. J Clin Endocrinol Metab 2011;96:3020-3030. Epub 2011 Aug 3

2. Weinstein LS, Yu S, Warner DR, Liu J. Endocrine manifestations of stimulatory $G$ protein alpha-subunit mutations and the role of genomic imprinting. Endocr Rev 2001;22:675-705.

3. Turan S, Bastepe M. The GNAS complex locus and human diseases associated with loss-of-function mutations or epimutations within this imprinted gene. Horm Res Paediatr 2013;80:229-241. Epub 2013 Oct 3

4. Levine MA. Pseudohypoparathyroidism. In: Bilezikian JP, Raisz LG, Rodan GA (eds). Principles of Bone Biology. New York, Academic Press, 2002;1137-1163

5. Bastepe M, Jüppner H. Pseudohypoparathyroidism. New insights into an old disease. Endocrinol Metab Clin North Am 2000;29:569-589.

6. Kehlenbach RH, Matthey J, Huttner WB. XL alpha s is a new type of G protein. Nature 1994;372:804-809.

7. Ischia R, Lovisetti-Scamihorn P, Hogue-Angeletti R, Wolkersdorfer M, Winkler H, Fischer-Colbrie R. Molecular cloning and characterization of NESP55, a novel chromogranin-like precursor of a peptide with 5-HT1B receptor antagonist activity. J Biol Chem 1997;272:11657-11662.

8. Ishikawa Y, Bianchi C, Nadal-Ginard B, Homcy CJ. Alternative promoter and 5' exon generate a novel Gs alpha mRNA. J Biol Chem 1990;265:8458-8462.

9. Swaroop A, Agarwal N, Gruen JR, Bick D, Weissman SM. Differential expression of novel Gs alpha signal transduction protein CDNA species. Nucleic Acids Res 1991;19:4725-4729.

10. Hayward BE, Bonthron DT. An imprinted antisense transcript at the human GNAS1 locus. Hum Mol Genet 2000;9:835-841 
11. Wroe SF, Kelsey G, Skinner JA, Bodle D, Ball ST, Beechey CV, Peters J, Williamson CM. An imprinted transcript, antisense to Nesp, adds complexity to the cluster of imprinted genes at the mouse Gnas locus. Proc Natl Acad Sci U S A 2000;97:3342-3346.

12. Yu S, Yu D, Lee E, Eckhaus M, Lee R, Corria Z, Accili D, Westphal $\mathrm{H}$, Weinstein LS. Variable and tissue-specific hormone resistance in heterotrimeric Gs protein alpha-subunit (Gsalpha) knockout mice is due to tissue-specific imprinting of the gsalpha gene. Proc Natl Acad Sci U S A 1998; 95:8715-8720.

13. Williamson CM, Ball ST, Nottingham WT, Skinner JA, Plagge A, Turner MD, Powles N, Hough T, Papworth D, Fraser WD, Maconochie M, Peters J. A cis-acting control region is required exclusively for the tissue-specific imprinting of Gnas. Nat Genet 2004;36:894-899. Epub 2004 Jul 25

14. Mantovani G, Ballare E, Giammona E, Beck-Peccoz P, Spada A. The gsalpha gene: predominant maternal origin of transcription in human thyroid gland and gonads. J Clin Endocrinol Metab 2002;87:4736-4740.

15. Germain-Lee EL, Ding CL, Deng Z, Crane JL, Saji M, Ringel MD, Levine MA. Paternal imprinting of Galpha(s) in the human thyroid as the basis of TSH resistance in pseudohypoparathyroidism type 1a. Biochem Biophys Res Commun 2002;296:67-72.

16. Liu J, Erlichman B, Weinstein LS. The stimulatory G protein alphasubunit Gs alpha is imprinted in human thyroid glands: implications for thyroid function in pseudohypoparathyroidism types $1 \mathrm{~A}$ and $1 \mathrm{~B}$. J Clin Endocrinol Metab 2003;88:4336-4341.

17. Chen M, Wang J, Dickerson KE, Kelleher J, Xie T, Gupta D, Lai EW, Pacak K, Gavrilova O, Weinstein LS. Central nervous system imprinting of the $\mathrm{G}$ protein $\mathrm{G}(\mathrm{s})$ alpha and its role in metabolic regulation. Cell Metab 2009;9:548-555.

18. Hayward BE, Barlier A, Korbonits M, Grossman AB, Jacquet P, Enjalbert A, Bonthron DT. Imprinting of the G(s)alpha gene GNAS1 in the pathogenesis of acromegaly. J Clin Invest 2001;107:R31-R36.

19. Albright F, Burnett $\mathrm{CH}$, Smith PH, Parson W. Pseudohypoparathyroidism - an example of "Seabright-Bantam syndrome". Endocrinology 1942;30:922-932.

20. Bastepe M, Weinstein LS, Ogata $N$, Kawaguchi $H$, Jüppner $H$, Kronenberg HM, Chung UI. Stimulatory G protein directly regulates hypertrophic differentiation of growth plate cartilage in vivo. Proc Natl Acad Sci U S A 2004;101:14794-14799. Epub 2004 Sep 30

21. Huso DL, Edie S, Levine MA, Schwindinger W, Wang Y, Jüppner H, Germain-Lee EL. Heterotopic ossifications in a mouse model of albright hereditary osteodystrophy. PLoS One 2011;6:e21755. Epub 2011 Jun 29

22. Mouallem M, Shaharabany M, Weintrob N, Shalitin S, Nagelberg N, Shapira H, Zadik Z, Farfel Z. Cognitive impairment is prevalent in pseudohypoparathyroidism type Ia, but not in pseudopseudohypoparathyroidism: possible cerebral imprinting of Gsalpha. Clin Endocrinol (Oxf) 2008;68:233-239. Epub 2007 Sep 4

23. Long DN, McGuire S, Levine MA, Weinstein LS, Germain-Lee EL. Body mass index differences in pseudohypoparathyroidism type 1 a versus pseudopseudohypoparathyroidism may implicate paternal imprinting of Galpha(s) in the development of human obesity. J Clin Endocrinol Metab 2007;92:1073-1079. Epub 2006 Dec 12

24. Chase LR, Melson GL, Aurbach GD. Pseudohypoparathyroidism: defective excretion of $3^{\prime}, 5^{\prime}$-AMP in response to parathyroid hormone. J Clin Invest 1969;48:1832-1844.

25. Drezner M, Neelon FA, Lebovitz HE. Pseudohypoparathyroidism type II: a possible defect in the reception of the cyclic AMP signal. N Engl J Med 1973;289:1056-1060.

26. Turan S, Thiele S, Tafaj O, Brix B, Atay Z, Abali S, Haliloglu B, Bereket A, Bastepe M. Evidence of hormone resistance in a pseudo- pseudohypoparathyroidism patient with a novel paternal mutation in GNAS. Bone 2015;71:53-57. Epub 2014 Oct 18

27. de Nanclares GP, Fernández-Rebollo E, Santin I, Garcia-Cuartero B, Gaztambide S, Menéndez E, Morales MJ, Pombo M, Bilbao JR, Barros F, Zazo N, Ahrens W, Jüppner H, Hiort O, Castaño L, Bastepe M. Epigenetic defects of GNAS in patients with pseudohypoparathyroidism and mild features of Albright's hereditary osteodystrophy. J Clin Endocrinol Metab 2007;92:2370-2373. Epub 2007 Apr 3

28. Mariot V, Maupetit-Méhouas S, Sinding C, Kottler ML, Linglart A. A maternal epimutation of GNAS leads to Albright osteodystrophy and parathyroid hormone resistance. J Clin Endocrinol Metab 2008;93:661665. Epub 2008 Jan 8

29. Unluturk U, Harmanci A, Babaoglu M, Yasar U, Varli K, Bastepe M, Bayraktar M. Molecular diagnosis and clinical characterization of pseudohypoparathyroidism type-Ib in a patient with mild Albright's hereditary osteodystrophy-like features, epileptic seizures, and defective renal handling of uric acid. Am J Med Sci 2008;336:84-90.

30. Mantovani G, de Sanctis L, Barbieri AM, Elli FM, Bollati V, Vaira V, Labarile P, Bondioni S, Peverelli E, Lania AG, Beck-Peccoz P, Spada A. Pseudohypoparathyroidism and GNAS epigenetic defects: clinical evaluation of albright hereditary osteodystrophy and molecular analysis in 40 patients. J Clin Endocrinol Metab 2010;95:651-658. Epub 2010 Jan 8

31. Mitsui T, Nagasaki K, Takagi M, Narumi S, Ishii T, Hasegawa T. A family of pseudohypoparathyroidism type Ia with an 850-kb submicroscopic deletion encompassing the whole GNAS locus. Am J Med Genet A 2012;158A:261-264. Epub 2011 Dec 2

32. Zazo C, Thiele S, Martín C, Fernandez-Rebollo E, Martinez-Indart L, Werner R, Garin I; Spanish PHP Group, Hiort O, Perez de Nanclares G. Gs $\alpha$ activity is reduced in erythrocyte membranes of patients with psedohypoparathyroidism due to epigenetic alterations at the GNAS locus. J Bone Miner Res 2011;26:1864-1870.

33. Linglart A, Carel JC, Garabédian M, Lé T, Mallet E, Kottler ML. GNAS1 lesions in pseudohypoparathyroidism Ia and Ic: genotype phenotype relationship and evidence of the maternal transmission of the hormonal resistance. J Clin Endocrinol Metab 2002;87:189-197.

34. Brix B, Werner R, Staedt P, Struve D, Hiort O, Thiele S. Different pattern of epigenetic changes of the GNAS gene locus in patients with pseudohypoparathyroidism type Ic confirm the heterogeneity of underlying pathomechanisms in this subgroup of pseudohypoparathyroidism and the demand for a new classification of GNAS-related disorders. J Clin Endocrinol Metab 2014;99:E1564-1570. Epub 2014 May 30

35. Thiele S, de Sanctis L, Werner R, Grötzinger J, Aydin C, Jüppner H, Bastepe M, Hiort O. Functional characterization of GNAS mutations found in patients with pseudohypoparathyroidism type Ic defines a new subgroup of pseudohypoparathyroidism affecting selectively Gs $\alpha$ receptor interaction. Hum Mutat 2011;32:653-660. Epub 2011 Apr 12

36. Lebrun M, Richard N, Abeguilé G, David A, Coëslier Dieux A, Journel H, Lacombe D, Pinto G, Odent S, Salles JP, Taieb A, Gandon-Laloum S, Kottler ML. Progressive osseous heteroplasia: a model for the imprinting effects of GNAS inactivating mutations in humans. J Clin Endocrinol Metab 2010;95:3028-3038. Epub 2010 Apr 28

37. Kaplan FS, Shore EM. Progressive osseous heteroplasia. J Bone Miner Res 2000;15:2084-2094.

38. Eddy MC, Jan De Beur SM, Yandow SM, McAlister WH, Shore EM, Kaplan FS, Whyte MP, Levine MA. Deficiency of the alpha-subunit of the stimulatory G protein and severe extraskeletal ossification. J Bone Miner Res 2000;15:2074-2083.

39. Cairns DM, Pignolo RJ, Uchimura T, Brennan TA, Lindborg CM, Xu M, Kaplan FS, Shore EM, Zeng L. Somitic disruption of GNAS in 
chick embryos mimics progressive osseous heteroplasia. J Clin Invest 2013;123:3624-3633. Epub 2013 Jul 25

40. Linglart A, Menguy C, Couvineau A, Auzan C, Gunes Y, Cancel M, Motte E, Pinto G, Chanson P, Bougnères P, Clauser E, Silve C. Recurrent PRKAR1A mutation in acrodysostosis with hormone resistance. N Engl J Med 2011;364:2218-2226

41. Michot C, Le Goff C, Goldenberg A, Abhyankar A, Klein C, Kinning E, Guerrot AM, Flahaut P, Duncombe A, Baujat G, Lyonnet S, Thalassinos C, Nitschke P, Casanova JL, Le Merrer M, Munnich A, Cormier-Daire V. Exome sequencing identifies PDE4D mutations as another cause of acrodysostosis. Am J Hum Genet 2012;90:740-745. Epub 2012 Mar 29

42. Lee H, Graham JM Jr, Rimoin DL, Lachman RS, Krejci P, Tompson SW, Nelson SF, Krakow D, Cohn DH. Exome sequencing identifies PDE4D mutations in acrodysostosis. Am J Hum Genet 2012;90:746-751. Epub 2012 Mar 29

43. Maroteaux P, Malamut G. [Acrodysostosis]. Presse Med 1968;76:21892192.

44. Robinow M, Pfeiffer RA, Gorlin RJ, McKusick VA, Renuart AW, Johnson GF, Summitt RL. Acrodysostosis. A syndrome of peripheral dysostosis, nasal hypoplasia, and mental retardation. Am J Dis Child 1971;121:195203.

45. Reiter S. Acrodysostosis. A case of peripheral dysostosis, nasal hypoplasia, mental retardation and impaired hearing. Pediatr Radiol 1978;7:53-55.

46. Davies SJ, Hughes HE. Familial acrodysostosis: can it be distinguished from Albright's hereditary osteodystrophy? Clin Dysmorphol 1992;1:207-215.

47. Silve C, Le-Stunff C, Motte E, Gunes Y, Linglart A, Clauser E. Acrodysostosis syndromes. Bonekey Rep 2012;1:225.

48. Ablow RC, Hsia YE, Brandt IK. Acrodysostosis coinciding with pseudohypoparathyroidism and pseudo-pseudohypoparathyroidism. AJR Am J Roentgenol 1977;128:95-99.

49. Linglart A, Fryssira H, Hiort O, Holterhus PM, Perez de Nanclares G, Argente J, Heinrichs C, Kuechler A, Mantovani G, Leheup B, Wicart P, Chassot V, Schmidt D, Rubio-Cabezas Ó, Richter-Unruh A, Berrade S, Pereda A, Boros E, Muñoz-Calvo MT, Castori M, Gunes Y, Bertrand G, Bougnères $P$, Clauser E, Silve C. PRKAR1A and PDE4D mutations cause acrodysostosis but two distinct syndromes with or without GPCRsignaling hormone resistance. J Clin Endocrinol Metab 2012;97:E23282338. Epub 2012 Oct 5

50. Nagasaki K, Iida T, Sato H, Ogawa Y, Kikuchi T, Saitoh A, Ogata T, Fukami M. PRKAR1A mutation affecting cAMP-mediated G proteincoupled receptor signaling in a patient with acrodysostosis and hormone resistance. J Clin Endocrinol Metab 2012;97:E1808-1813. Epub 2012 Jun 20

51. Maass PG, Aydin A, Luft FC, Schächterle C, Weise A, Stricker S, Lindschau C, Vaegler M, Qadri F, Toka HR, Schulz H, Krawitz PM, Parkhomchuk D, Hecht J, Hollfinger I, Wefeld-Neuenfeld Y, BartelsKlein E, Mühl A, Kann M, Schuster H, Chitayat D, Bialer MG, Wienker TF, Ott J, Rittscher K, Liehr T, Jordan J, Plessis G, Tank J, Mai K, Naraghi R, Hodge R, Hopp M, Hattenbach LO, Busjahn A, Rauch A, Vandeput F, Gong M, Rüschendorf F, Hübner N, Haller H, Mundlos S, Bilginturan N, Movsesian MA, Klussmann E, Toka O, Bähring S. PDE3A mutations cause autosomal dominant hypertension with brachydactyly. Nat Genet 2015;47:647-653. Epub 2015 May 11

52. Thiele S, Mantovani G, Barlier A, Boldrin V, Bordogna P, De Sanctis L, Elli FM, Freson K, Garin I, Grybek V, Hanna P, Izzi B, Hiort O, Lecumberri B, Pereda A, Saraff V, Silve C, Turan S, Usardi A, Werner R, de Nanclares GP, Linglart A. From pseudohypoparathyroidism to inactivating PTH/ PTHrP signalling disorder (iPPSD), a novel classification proposed by the EuroPHP network. Eur J Endocrinol 2016;175:P1-P17. Epub 2016 Jul 11
53. Schroeder HW Jr, Zasloff M. The hand and foot malformations in fibrodysplasia ossificans progressiva. Johns Hopkins Med J 1980;147:73-78.

54. Benet-Pagès A, Orlik P, Strom TM, Lorenz-Depiereux B. An FGF23 missense mutation causes familial tumoral calcinosis with hyperphosphatemia. Hum Mol Genet 2005;14:385-390. Epub 2004 Dec 8

55. Temtamy SA, Aglan MS. Brachydactyly. Orphanet J Rare Dis 2008;3:15.

56. Pereda A, Garin I, Garcia-Barcina M, Gener B, Beristain E, Ibañez AM, Perez de Nanclares G. Brachydactyly E: isolated or as a feature of a syndrome. Orphanet J Rare Dis 2013;8:141.

57. Levine MA, Jap TS, Mauseth RS, Downs RW, Spiegel AM. Activity of the stimulatory guanine nucleotide-binding protein is reduced in erythrocytes from patients with pseudohypoparathyroidism and pseudopseudohypoparathyroidism: biochemical, endocrine, and genetic analysis of Albright's hereditary osteodystrophy in six kindreds. J Clin Endocrinol Metab 1986;62:497-502.

58. Patten JL, Levine MA. Immunochemical analysis of the alpha-subunit of the stimulatory G-protein of adenylyl cyclase in patients with Albright's hereditary osteodystrophy. J Clin Endocrinol Metab 1990;71:12081214.

59. Levine MA, Ahn TG, Klupt SF, Kaufman KD, Smallwood PM, Bourne HR, Sullivan KA, Van Dop C. Genetic deficiency of the alpha subunit of the guanine nucleotide-binding protein $\mathrm{Gs}$ as the molecular basis for Albright hereditary osteodystrophy. Proc Natl Acad Sci U S A 1988;85:617-621

60. de Sanctis L, Giachero F, Mantovani G, Weber G, Salerno M, Baroncelli GI, Elli MF, Matarazzo P, Wasniewska M, Mazzanti L, Scirè G, Tessaris D. Genetic and epigenetic alterations in the GNAS locus and clinical consequences in Pseudohypoparathyroidism: Italian common healthcare pathways adoption. Ital J Pediatr 2016;42:101.

61. Poznanski AK, Werder EA, Giedion A, Martin A, Shaw H. The pattern of shortening of the bones of the hand in PHP and PPHP--A comparison with brachydactyly E, Turner Syndrome, and acrodysostosis. Radiology 1977;123:707-718.

62. Cervantes CD, Lifshitz F, Levenbrown J. Radiologic anthropometry of the hand in patients with familial short stature. Pediatr Radiol 1988;18:210-214.

63. Archibald RM, Finby N, De Vito F. Endocrine significance of short metacarpals. J Clin Endocrinol Metab 1959;19:1312-1322.

64. Slater SA. Evaluation of metacarpal sign (Short fourth metacarpal). Pediatrics. 1970;46:468-471.

65. Poznanski AK, Garn SM, Nagy JM, Gall JC Jr. Metacarpophalangeal pattern profiles in the evaluation of skeletal malformations. Radiology 1972;104:1-11.

66. Balavoine AS, Ladsous M, Velayoudom FL, Vlaeminck V, Cardot-Bauters C, d'Herbomez M, Wemeau JL. Hypothyroidism in patients with pseudohypoparathyroidism type Ia: clinical evidence of resistance to TSH and TRH. Eur J Endocrinol 2008;159:431-437.

67. Vlaeminck-Guillem V, D'herbomez M, Pigny P, Fayard A, Bauters C, Decoulx M, Wémeau JL. Pseudohypoparathyroidism Ia and hypercalcitoninemia. J Clin Endocrinol Metab 2001;86:3091-3096.

68. Weisman Y, Golander A, Spirer Z, Farfel Z. Pseudohypoparathyroidism type $1 \mathrm{a}$ presenting as congenital hypothyroidism. J Pediatr 1985;107:413-415.

69. Romanet P, Osei L, Netchine I, Pertuit M, Enjalbert A, Reynaud $\mathrm{R}$, Barlier A. Case report of GNAS epigenetic defect revealed by a congenital hypothyroidism. Pediatrics 2015;135:e1079-1083.

70. Germain-Lee EL, Groman J, Crane JL, Jan de Beur SM, Levine MA. Growth hormone deficiency in pseudohypoparathyroidism type $1 \mathrm{a}$ : another manifestation of multihormone resistance. J Clin Endocrinol Metab 2003;88:4059-4069. 
71. Mantovani G, Maghnie M, Weber G, De Menis E, Brunelli V, Cappa M, Loli P, Beck-Peccoz P, Spada A. Growth hormone-releasing hormone resistance in pseudohypoparathyroidism type ia: new evidence for imprinting of the Gs alpha gene. J Clin Endocrinol Metab 2003;88:40704074.

72. de Sanctis L, Bellone J, Salerno M, Faleschini E, Caruso-Nicoletti M, Cicchetti M, Concolino D, Balsamo A, Buzi F, Ghizzoni L, de Sanctis C. $\mathrm{GH}$ secretion in a cohort of children with pseudohypoparathyroidism type Ia. J Endocrinol Invest 2007;30:97-103.

73. Namnoum AB, Merriam GR, Moses AM, Levine MA. Reproductive dysfunction in women with Albright's hereditary osteodystrophy. J Clin Endocrinol Metab 1998;83:824-829.

74. Linglart A, Carel JC, Garabédian M, Lé T, Mallet E, Kottler ML. GNAS1 lesions in pseudohypoparathyroidism Ia and Ic: genotype phenotype relationship and evidence of the maternal transmission of the hormonal resistance. J Clin Endocrinol Metab 2002;87:189-197.

75. Levine MA, Downs RW Jr, Moses AM, Breslau NA, Marx SJ, Lasker RD, Rizzoli RE, Aurbach GD, Spiegel AM. Resistance to multiple hormones in patients with pseudohypoparathyroidism. Association with deficient activity of guanine nucleotide regulatory protein. Am J Med 1983;74:545-556.

76. Carel JC, Le Stunff C, Condamine L, Mallet E, Chaussain JL, Adnot P, Garabédian M, Bougnères P. Resistance to the lipolytic action of epinephrine: a new feature of protein Gs deficiency. J Clin Endocrinol Metab 1999;84:4127-4131.

77. Thiele S, Werner R, Grötzinger J, Brix B, Staedt P, Struve D, Reiz B, Farida J, Hiort O. A positive genotype-phenotype correlation in a large cohort of patients with Pseudohypoparathyroidism Type Ia and Pseudo-pseudohypoparathyroidism and 33 newly identified mutations in the GNAS gene. Mol Genet Genomic Med 2015;3:111-120. Epub 2014 Dec 4

78. Mouallem M, Shaharabany M, Weintrob N, Shalitin S, Nagelberg N, Shapira H, Zadik Z, Farfel Z. Cognitive impairment is prevalent in pseudohypoparathyroidism type la, but not in pseudopseudohypoparathyroidism: possible cerebral imprinting of Gsalpha. Clin Endocrinol (Oxf) 2008;68:233-239. Epub 2007 Sep 4

79. Geneviève D, Sanlaville D, Faivre L, Kottler ML, Jambou M, Gosset P, Boustani-Samara D, Pinto G, Ozilou C, Abeguilé G, Munnich A, Romana $\mathrm{S}$, Raoul O, Cormier-Daire V, Vekemans M. Paternal deletion of the GNAS imprinted locus (including Gnasxl) in two girls presenting with severe pre- and post-natal growth retardation and intractable feeding difficulties. Eur J Hum Genet 2005;13:1033-1039.

80. Baple EL, Poole RL, Mansour S, Willoughby C, Temple IK, Docherty LE, Taylor R, Mackay DJ. An atypical case of hypomethylation at multiple imprinted loci. Eur J Hum Genet 2011;19:360-362. Epub 2011 Jan 5

81. Demura M, Takeda Y, Yoneda T, Furukawa K, Tachi A, Mabuchi H. Completely skewed $\mathrm{X}$-inactivation in a mentally retarded young female with pseudohypoparathyroidism type IB and juvenile renin-dependent hypertension. J Clin Endocrinol Metab 2003;88:3043-3049.

82. Kadilli I, Colicchio S, Guglielmo R, Vollono C, Della Marca G, Janiri L. Clinical insights by the presence of bipolar disorder in pseudohypoparathyroidism type 1A. Gen Hosp Psychiatry 2015;37:497.e3-5. Epub 2015 Jun 16

83. Maupetit-Méhouas S, Azzi S, Steunou V, Sakakini N, Silve C, Reynes C, Perez de Nanclares G, Keren B, Chantot S, Barlier A, Linglart A, Netchine I. Simultaneous hyper- and hypomethylation at imprinted loci in a subset of patients with GNAS epimutations underlies a complex and different mechanism of multilocus methylation defect in pseudohypoparathyroidism type 1b. Hum Mutat 2013;34:1172-1180. Epub 2013 May 28

84. Richard N, Molin A, Coudray N, Rault-Guillaume P, Jüppner H, Kottler ML. Paternal GNAS mutations lead to severe intrauterine growth retardation (IUGR) and provide evidence for a role of XLas in fetal development. J Clin Endocrinol Metab 2013;98:E1549-1556. Epub 2013 Jul 24

85. Plagge A, Gordon E, Dean W, Boiani R, Cinti S, Peters J, Kelsey G. The imprinted signaling protein $\mathrm{XL}$ alpha $\mathrm{s}$ is required for postnatal adaptation to feeding. Nat Genet 2004;36:818-826. Epub 2004 Jul 25

86. Xie T, Plagge A, Gavrilova O, Pack S, Jou W, Lai EW, Frontera M, Kelsey G, Weinstein LS. The alternative stimulatory G protein alpha-subunit XLalphas is a critical regulator of energy and glucose metabolism and sympathetic nerve activity in adult mice. J Biol Chem 2006;281:1898918999. Epub 2006 May 2

87. Bréhin AC, Colson C, Maupetit-Méhouas S, Grybek V, Richard N, Linglart A, Kottler ML, Jüppner H. Loss of methylation at GNAS exon $\mathrm{A} / \mathrm{B}$ is associated with increased intrauterine growth. J Clin Endocrinol Metab 2015;100:E623-631. Epub 2015 Jan 20

88. Germain-Lee EL. Short stature, obesity, and growth hormone deficiency in pseudohypoparathyroidism type 1a. Pediatr Endocrinol Rev 2006;3 (Suppl 2):318-327.

89. Duchatelet S, Ostergaard E, Cortes D, Lemainque A, Julier C. Recessive mutations in PTHR1 cause contrasting skeletal dysplasias in Eiken and Blomstrand syndromes. Hum Mol Genet 2005;14:1-5. Epub 2004 Nov 3

90. Kayemba-Kay's S, Tripon C, Heron A and Hindmarsh P. Pseudohypoparathyroidism Type 1A-Subclinical Hypothyroidism and Rapid Weight Gain as Early Clinical Signs: A Clinical Review of 10 Cases. J Clin Res Pediatr Endocrinol 2016;8:432-438.

91. Roizen JD, Danzig J, Groleau V, McCormack S, Casella A, Harrington J, Sochett E, Tershakovec A, Zemel BS, Stallings VA, Levine MA. Resting Energy Expenditure Is Decreased in Pseudohypoparathyroidism Type 1A. J Clin Endocrinol Metab 2016;101:880-888. Epub 2015 Dec 28

92. Shoemaker AH, Lomenick JP, Saville BR, Wang W, Buchowski MS, Cone RD. Energy expenditure in obese children with pseudohypoparathyroidism type 1a. Int J Obes (Lond) 2013;37:11471153. Epub 2012 Dec 11

93. Lynch DC, Dyment DA, Huang L, Nikkel SM, Lacombe D, Campeau PM, Lee B, Bacino CA, Michaud JL, Bernier FP; FORGE Canada Consortium, Parboosingh JS, Innes AM. Identification of novel mutations confirms PDE4D as a major gene causing acrodysostosis. Hum Mutat 2013;34:97102. Epub 2012 Nov 9

94. Faroogi S. Obesity genes-it's all about the parents! Cell Metab 2009;9:487-488.

95. Klopocki E, Hennig BP, Dathe K, Koll R, de Ravel T, Baten E, Blom E, Gillerot Y, Weigel JF, Krüger G, Hiort O, Seemann P, Mundlos S. Deletion and point mutations of PTHLH cause brachydactyly type E. Am J Hum Genet 2010;86:434-439. Epub 2010 Feb 18

96. Thomas-Teinturier C, Pereda A, Garin I, Diez-Lopez I, Linglart A, Silve C, de Nanclares GP. Report of two novel mutations in PTHLH associated with brachydactyly type E and literature review. Am J Med Genet A 2016;170:734-742. Epub 2015 Dec 6 